Original paper

\title{
Death of super-continents and birth of oceans heralded by discrete A-type granite igneous events: the case of the Variscan-Alpine Europe
}

\author{
Bernard BONIN
}

UMR 8148 'IDES, Département des Sciences de la Terre, Bâtiment 504, Université de Paris-Sud, F-91405 ORSAY CEDEX, France; bernard.bonin@u-psud.fr

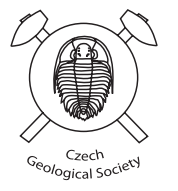

Granitoids occupy large areas of the Variscan-Alpine Europe. The specific group of A-type granites identifies postcollisional (post-orogenic) and anorogenic geodynamic settings. Post-orogenic igneous provinces are emplaced during the very last episodes of supercontinent amalgamation. Anorogenic igneous provinces accompany continental break-up and predate the development of new oceanic basins. Though not voluminous compared with the other granite types, A-type granites substantiate critical periods of the life of supercontinents.

Their ages of emplacement in the Variscan-Alpine Europe span the entire Cambrian-Triassic time interval. They are not random, however, and correspond to discrete episodes. Two major age groupings, both with a $c$. 60 My duration, are distinguished. The Early Cambrian-Early Ordovician period corresponds to Pannotia amalgamation, followed by its break-up and the development of the Rheic-Proto-Tethys Ocean. The Late Carboniferous-Early Triassic period corresponds to Rheic closure and Pangaea amalgamation, followed by its break-up and the development of the NeoTethys Ocean. Devonian-Early Carboniferous A-type igneous episodes, scarce in Europe but widespread in Central Asia, accompanied the development of the Palaeo-Tethys Ocean.

Keywords: A-type granite, geodynamic settings, Palaeozoic, Cadomian, Variscan, Triassic, Europe

Received: 14 November 2008; accepted 10 January 2009; handling editor: D. Dolejš

\section{Introduction}

Granitoids are extensively studied for the following reasons: (i) they are the most abundant rocks in the Earth's upper continental crust, (ii) like other igneous rocks, they represent probes into the deep planetary interiors, and (iii) they are closely connected with tectonics as well as geodynamics. Even now, the proportion of granitoids and associated volcanic rocks present on Earth is low, about $0.1 \%$ of the Bulk Earth (Clarke 1996). Such a small proportion corresponds nevertheless to a total mass of at least $10^{22} \mathrm{~kg}$ and a volume of about $3.74 \times 10^{9} \mathrm{~km}^{3}$ (Bonin et al. 2002). Roughly $86 \mathrm{vol}$ \% of the upper continental crust is granitic in composition (Wedepohl 1991). Granite occurs also, albeit in smaller amounts, within lower continental crust, oceanic crust, upper mantle and meteorites (Bonin et al. 2002; Bonin and Bébien 2005, and references therein).

In this Special Issue devoted to 'Field, analytical and experimental approaches to silicic magmatism in collisional orogens', the aim of this paper is to provide an overview of the occurrences and geodynamic settings of Cambrian to Triassic A-type granites within the Variscan-Alpine Europe, i.e. the peri-Gondwanan terranes that collided with Baltica during the Palaeozoic era, before being collided by the rest of Gondwana during the Permian.
A-type granites were first named by Loiselle and Wones (1979). Further refinements (for a review, see Bonin 2007) led to a proposal of clear criteria that are commonly used to distinguish A-type granites from the other granite types worldwide (Tab. 1). They were ascribed for a long time (e.g., Billings 1945; Black et al. 1985) to the specific geodynamic settings, namely post-collisional to within-plate, which gives them the popular name of 'anorogenic'. Examples of tectonic settings of A-type igneous provinces occurring in Europe are listed in Tab. 2.

Three issues will be addressed. The first concerns the so-called "crustal signatures" yielded by radiogenic isotopes in otherwise mantle-derived rocks. The second is the problem of identifying undoubtedly A-type granites emplaced within polygenetic orogenic belts, after they suffered deformation and alteration and were converted into orthogneisses. The last one consists of a critical overview of A-type igneous provinces emplaced during the build-up of the Variscan-Alpine Europe.

\section{What is A-type granite?}

A-type granites constitute a well-defined type of silicic igneous rocks. The concept and usage of the term "A-type" follow closely the recommendations of the UNESCO-IGCP Project 510 "A-type granites and related 


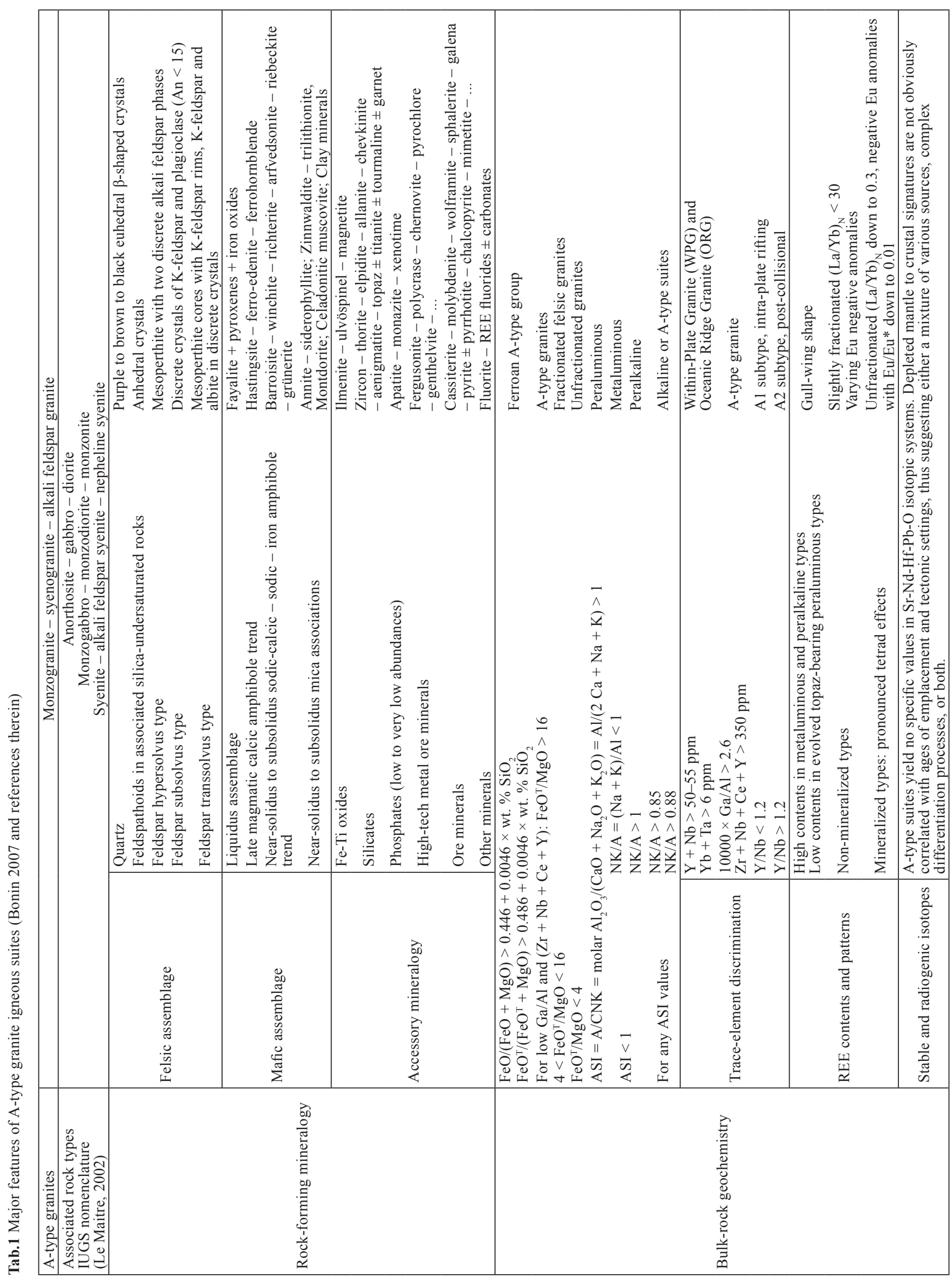


rocks through time" discussed in its first meeting in 2005 (Bonin 2007). Clear criteria, involving specific petrological-mineralogical features and geochemical compositions (e.g., Pearce et al. 1984; Whalen et al. 1987; Eby 1990) commonly used to identify A-type granites, are listed in Tab. 1. In addition, A-type granites are not emplaced randomly in continental areas, as their tectonic settings involve always some amounts of extension (Tab. 2). Last, in agreement with their original definition (Loiselle and Wones 1979), they are associated with coeval mafic to intermediate rocks within compositionally expanded igneous suites (e.g., Bonin et al. 2008).

\subsection{A-type granites and A-type granites?}

No radiogenic and stable isotopic criteria (e.g., Sr, Nd, Hf, $\mathrm{Pb}, \mathrm{O})$ can define A-type granites unambiguously, thus raising the question whether we are dealing with a too vague concept. Most popular textbooks on igneous petrology usually consider granites as a specific entity genetically unrelated to other igneous, plutonic and volcanic, suites. Because they yield variable isotopic signatures, granites are also frequently regarded as entirely of crustal derivation, with or without hybridization by varying amounts of mantle-derived mafic magmas. This is, in particular, the basic scheme of the $\mathrm{S}-\mathrm{I}-\mathrm{M}$ alphabetical classification. However, A-type granites differ from the other granite types in that, though crustal sources seem to be evidenced in many cases by the isotopic record, no migmatitic terranes on Earth have yielded any leucosomes of A-type compositions, nor had experimental petrology succeeded in producing unambiguous A-type liquids from crustal materials (for a discussion, see Bonin 2007 and references therein). On the contrary, occurrences of A-type granites within oceanic islands and even on the Moon indicate they are likely to form through mineral fractionation, not partial melting, of mafic magmas, even in the absence of significant amounts of $\mathrm{H}_{2} \mathrm{O}$ (Bonin et al. 2002).

\subsection{The crustal issue}

The isotopic "crustal signature" constitutes an important issue to address. Geoscientists involved in upper mantle studies are well aware of enriched compositions that can mimic crustal values. In the lack of evidence for preserved primitive mantle reservoirs, occurrences of various enriched mantle end-members are explained by subduction-induced incorporation of crustal (oceanic and continental) materials into depleted upper mantle of the overriding lithospheric plate.

Consider a depleted mantle of harzburgitic composition and add either continental upper crustal materials, or TTG-like silicic liquids produced from oceanic crust. Abundances of incompatible elements within harzburgite are exceedingly low. Addition of small volumes of products rich in incompatible elements results in harzburgite converted into re-fertilized lherzolite and/or websterite, with an overall signature strongly influenced by crustal materials. Isotopic initial ratios and $\mathrm{Nd}$ depleted-mantle model ages yielded by magmas originating from such a [depleted mantle + crust] mixture stand, therefore, closer to the crustal than to the depleted mantle end-member.

There is, therefore, no need for a key role played by continental wall rocks, which A-type magmas pass through, or are emplaced in. As baffling as this idea can appear at a first glance, crustal signatures have little to do with the exposed crust. They have to be searched at deeper levels within the lithospheric keels of continental plates. Evolved low-P specialized granites can be strongly contaminated by exogenous elements carried by reactive $\mathrm{Cl}$ - and F-rich hydrothermal fluids. Their high initial ${ }^{87} \mathrm{Sr} /{ }^{86} \mathrm{Sr}$ ratios and low $\varepsilon_{\mathrm{Nd}}(\mathrm{t})$ values, totally unrelated to magma sources, constitute apparent exceptions that should be mentioned (e.g., Zinnwald-Cínovec granite).

\subsection{A unified view}

In the following pages, A-type granites will not be considered as a discrete entity unrelated to other coeval igneous rocks. The concept of A-type igneous suite involves not only A-type granites, but also mafic and intermediate, volcanic and plutonic, igneous rocks. Such suites include bimodal associations derived from tholeiitic and mildly alkaline basaltic magmas (Frost and Frost 2008). Though following apparently different evolutionary paths, their real unity was recognized for a long time within plu-

Tab. 2 Selected Phanerozoic A-type igneous suites in Europe (adapted from Bonin 2007)

\begin{tabular}{|c|c|c|c|}
\hline Orogenic stages & Tectonic settings & Examples & Ages \\
\hline Post-collision & Transcurrent shear zones & $\begin{array}{l}\text { Assynt Igneous Province, Scotland } \\
\text { Western Mediterranean Province } \\
\text { Comendite, San Pietro Island, Italy }\end{array}$ & $\begin{array}{c}440-425 \mathrm{Ma} \\
280-235 \mathrm{Ma} \\
15 \mathrm{Ma}\end{array}$ \\
\hline Rifts & Extensional regime & $\begin{array}{c}\text { Midland Valley, Scotland } \\
\text { Oslo Rift, Norway } \\
\text { Pantellerite, Pantelleria Island, Italy }\end{array}$ & $\begin{array}{c}\text { c. } 345 \mathrm{Ma} \\
280-250 \mathrm{Ma} \\
0.33-0.003 \mathrm{Ma}\end{array}$ \\
\hline Passive margins & Extensional regime & $\begin{array}{l}\text { Peralkaline gneisses, Galicia, Spain } \\
\text { Rheinisches Schiefergebirge, Germany } \\
\text { British Tertiary Igneous Province }\end{array}$ & $\begin{array}{l}500-480 \mathrm{Ma} \\
390-380 \mathrm{Ma} \\
\text { c. } 50 \mathrm{Ma}\end{array}$ \\
\hline
\end{tabular}


tonic-volcanic provinces, but it is still underestimated in granite studies. Keeping this idea in mind, it is not surprising that A-type granites do not have to be of only crustal derivation.

\section{The A-type orthogneiss conundrum}

A-type igneous suites are fairly easy to discriminate and have specific ferroan alkali-calcic to alkaline bulk-rock compositions. However, aluminous subsolvus granites do not have to yield specific features of A-type granite. In the case of post-orogenic igneous suites, in which they are abundant, it is not always straightforward to define whether they are A-type, or not. Field criteria are helpful, such as textures including euhedral shape of purple-brown-black quartz crystals and anhedral shape of biotite flakes.

\subsection{Interpretation of metamorphic textures and compositions}

Evidence for A-type granites highly deformed and involved within orogenic fold belts is generally not easy to decipher, because they lost partly their petrological and geochemical characteristics through mineral breakdown, leaching and/or re-crystallization. A-type orthogneisses usually carry a subsolvus feldspar assemblage, with K-feldspar only slightly to non-perthitic (Floor 1974). Alkali loss and silicification result into bulk rocks having non-igneous compositions, with less than 8 wt. \% of $\mathrm{Na}_{2} \mathrm{O}+\mathrm{K}_{2} \mathrm{O}$ and more than 78 wt. $\% \mathrm{SiO}_{2}$. A-type metagranites, with primary (igneous) peraluminous and metaluminous compositions, can yield metamorphicallyinduced, strongly peraluminous compositions that apparently resemble evolved S-type rocks. In orthogneisses issued from strongly peralkaline granites, though $(\mathrm{Na}$ $+\mathrm{K}) / \mathrm{Al}$ ratios can remain higher than 1.0, alkali loss is reflected by occurrence of newly formed bipyramidal zircon crystals and metamorphic riebeckite, a sodic amphibole with empty A-site, replacing igneous arfvedsonite, characterised by full occupancy of the A-site (Floor 1974). The HFSE contents can decrease through leaching by hydrothermal F-bearing fluids. In most cases, immobile elements can help, such as, e.g., fairly low (<14-15 wt. \%) $\mathrm{Al}_{2} \mathrm{O}_{3}$ contents, low $\mathrm{MgO} / \mathrm{FeO}_{\mathrm{T}}$ ratios and gull-wing shapes of REE patterns, diagnostic of Atype granite compositions.

The Randa orthogneiss (Thélin 1987) offers a pertinent example: this Permian ( $269 \pm 2 \mathrm{Ma}$, Roadian, Bussy et al. 1996) A-type granite underwent Alpine tectonic episodes under greenschist-facies conditions. The slightly deformed core of the massif yields its original ferroan alkali-calcic composition, with low $\mathrm{Fe}_{2} \mathrm{O}_{3} / \mathrm{FeO}$ ratio, 40-50 ppm Y and
15-30 ppm Nb, corresponding to the Within-Plate Granite (WPG) field of Pearce et al. (1984). The still ferroan sheared margins are highly silicic, with up to $81.5 \mathrm{wt} . \%$ $\mathrm{SiO}_{2}$, and calc-alkaline, due to decreasing alkali contents. They yield high $\mathrm{Fe}_{2} \mathrm{O}_{3} / \mathrm{FeO}$ ratios, low $\mathrm{TiO}_{2}$ contents, fairly constant (20-40 ppm) Y contents and low $(<10 \mathrm{ppm})$ to very low (below detection limit by the XRF method) $\mathrm{Nb}$ contents. They plot no longer in the WPG, but in the Volcanic-Arc Granite (VAG) field. Positive Y-Zr correlations indicate that zircon is the main carrier of $Y$ and that this element remains stable during the metamorphic overprint. Positive $\mathrm{Nb}-\mathrm{TiO}_{2}$ and negative $\mathrm{Nb}-\mathrm{Fe}_{2} \mathrm{O}_{3}$ correlations suggest breakdown of $\mathrm{Nb}$-bearing $\mathrm{Fe}-\mathrm{Ti}$ oxides and $\mathrm{Nb}$ mobility through oxidizing fluids.

\subsection{The problem of age determination of A-type orthogneiss protoliths}

High LILE mobility favours partial to complete resetting of $\mathrm{Rb}-\mathrm{Sr}$ isotopic systems; even $\mathrm{Sm}-\mathrm{Nd}$ systems can be disturbed in the presence of F-bearing fluids. The isochron method is, therefore, unable to provide reliable emplacement ages for the igneous protoliths. In the most favourable cases of complete resetting during major metamorphic events, it can provide ages of those events. Like the $\mathrm{Rb}-\mathrm{Sr}$ isotopic system, the $\mathrm{U}-\mathrm{Th}-\mathrm{Pb}$ isotopic system is also susceptible to variable amounts of resetting through $\mathrm{Pb}$ loss during hydrothermally mediated events. Zircon is currently in systematic use for age determination purposes, as well as other U-Th-bearing minerals, such as monazite and titanite. Abundant in nonperalkaline A-type granites, zircon precipitates either as early euhedral prismatic (100) crystals in fluid-deficient conditions, or as late euhedral to anhedral bipyramidal crystals in fluid-rich environments (Pupin et al. 1978). Early prismatic crystals are limpid, while late bipyramidal crystals are often metamict. Zircon usually cannot crystallize in Zr-rich peralkaline A-type granites, because of its high solubility in the magma, and is replaced by elpidite, a hydrous alkali zirconosilicate (Tab. 1).

Though stable under a wide range of conditions, zircon can re-crystallize during a metamorphic event forming new crystals and/or rims around igneous cores. In meta-igneous peralkaline rocks, secondary bipyramidal crystals result from alkali loss. Associated xenotime is frequent (Pan 1997). There is a range of textures between two zircon end-members. One end-member is a pristine generation of igneous crystals and/or cores, characterized by well-developed growth zoning evidenced by cathodoluminescence imaging, and the other end-member is a package of newly formed porous to skeletal metamorphic crystals and/or rims intergrown with secondary mineral inclusions, reflecting dissolution-re-precipitation processes (Tomaschek et al. 2003; Bendaoud et al. 2008). 
Thus, the crystal rims are likely to yield U-Pb ages differing from the crystal cores.

The ID-TIMS technique using populations of zircon crystals is unable to provide concordant isotopic dates in the case of rocks that have undergone multiple episodes of crystallization. Zircon crystals in A-type granites are generally devoid of inherited cores. Single crystals subjected to a removal of re-crystallized and/or metamict rims by the air abrasion technique can give concordant dates that are likely to indicate the emplacement age of the protolith. If re-crystallized metamorphic rims remain, results plot along a discordia line. In the most favourable cases, the upper intercept with the concordia curve yields the age of the protolith and the lower intercept the age of the metamorphic overprint. In the more difficult cases of aluminous A-type granites containing inherited cores, multiple discordia chords can be computed and should be interpreted. The seemingly promising evaporation technique precludes direct investigations on the parts of the crystal that are removed during incremental heating steps and the results are less precise than those obtained by the ID-TIMS technique.

With modern techniques using in situ isotopic measurements, these difficulties could be addressed. As igneous zircon incorporates $\mathrm{U}$ and $\mathrm{Th}$, according to zircon/liquid distribution coefficients for the two elements, $\mathrm{Th} / \mathrm{U}$ ratios measured in the crystals are higher than 0.2 and frequently higher than 0.5 . In the case of re-crystallization in the presence of coexisting solid phases, such as xenotime, $\mathrm{Th} / \mathrm{U}$ ratios in metamorphic zircon decrease considerably, down to less than 0.05 (Williams and Claesson 1987). In zoned crystals, igneous crystals and cores, with $\mathrm{Th} / \mathrm{U}$ ratios higher than 0.2 , can be distinguished from low $\mathrm{Th} / \mathrm{U}$ metamorphic crystals and rims, though igneous-like $\mathrm{Th} / \mathrm{U}$ ratios can be preserved in some metamorphic crystals (Tomaschek et al. 2003).

\subsection{Ordovician events within parts of the Iberian Peninsula}

The Early to Middle Ordovician igneous episodes in the Palaeozoic orogenic belt of Western Iberia afford a pertinent example. The Ossa-Morena Zone is bordered to the north by the autochthonous units of Central Iberia and Galicia-Trás-os-Montes and the Malpica-Tuy allochthon. The terrane assemblage, deformed and amalgamated during the Variscan orogenic event, corresponds to a volcanic passive margin developed since the Ediacaran-Early Cambrian transition (Simancas et al. 2004; Etxebarria et al. 2006). A-type orthogneisses are exposed within all units and their zircon crystals have been analysed for U$\mathrm{Pb}$ dating (e.g., Lancelot et al. 1985; Santo Zalduegui et al. 1995; Valverde-Vaquero et al. 2005; Bea et al. 2006; Cordani et al. 2006; Montero et al. 2008).
Ion microprobe and LA-ICPMS techniques allowed to obtain trace-element and isotopic data on zircon crystals of orthogneisses from Portalegre and Alcóçavas, OssaMorena Zone (Cordani et al. 2006), Galiñeiro, Galicia (Montero et al. 2008), and Miranda do Douro, Central Iberian Zone (Bea et al. 2006). The evolution of $\mathrm{Th} / \mathrm{U}$ ratios with time (Fig. 1) constitutes a good marker of the origin of zircon crystals. The 370-340 Ma (Variscan) crystals and rims yield consistently low Th contents and $\mathrm{Th} / \mathrm{U}$ ratios, from 0.12 to 0.03 , substantiating metamorphic crystallization.

In the Portalegre orthogneiss, a single population of crystals yields a concordant age of $497 \pm 10 \mathrm{Ma}$, with no obvious inherited cores (Fig. 1). Igneous crystals yield 109 to $363 \mathrm{ppm} \mathrm{U}$ and igneous $\mathrm{Th} / \mathrm{U}$ ratios from 0.15 to 1.43 , suggesting that they crystallized at various stages from liquidus to solidus. One non-igneous U-rich (682 $\mathrm{ppm})$, low-Th/U (0.09), yet concordant crystal is likely to have precipitated in subsolidus conditions from latestage fluids.

In the Alcóçavas orthogneiss, two populations of crystals yield concordant ages of $539 \pm 20 \mathrm{Ma}$ and 464 $\pm 14 \mathrm{Ma}$, with one $2.5 \mathrm{Ga}$ inherited core and one 620 Ma highly discordant crystal. The $\mathrm{Th} / \mathrm{U}$ ratios are higher than 0.22 in the $464 \mathrm{Ma}$ crystals and 0.18 in the $539 \mathrm{Ma}$ crystals, implying that both populations grew from magmas (Fig. 1). Rounded shapes displayed by some crystals suggest that all 539 Ma crystals are inherited from Early Cambrian igneous formations. The emplacement age of the protolith to the Alcóçavas orthogneiss is, therefore, Middle Ordovician.

In the Galiñeiro peralkaline orthogneiss, abundant zircon crystals are brown, turbid, totally or partially metamict, thus apparently not suitable for $\mathrm{U}-\mathrm{Pb}$ dating. However, SIMS analyses yield a mean common $\mathrm{Pb}$ corrected age of $482 \pm 2 \mathrm{Ma}$, considered as the age of emplacement. U and Th contents, $265-5827 \mathrm{ppm}$ and 30-641 ppm, respectively, and $\mathrm{Th} / \mathrm{U}$ ratios ranging from $0.64-0.17$ (igneous, $50 \%$ spots) to $0.14-0.01$ (secondary) show that zircon crystallized under magmatic to subsolidus conditions and that late-stage fluids were coeval to the emplacement of the peralkaline protolith (Fig. 1).

Like other metavolcanic and metagranitic rocks of the Ollo de Sapo Formation of the Central Iberian Zone (Parga-Pondal et al. 1964; Montero et al. 2007), the magnesian calc-alkaline Miranda do Douro orthogneiss does not display A-type characteristics. Its age of emplacement is currently a matter of controversy. Based on upper intercept in $\mathrm{U}-\mathrm{Pb}$ concordia diagram, a $618 \pm 9 \mathrm{Ma}$ age was reported by Lancelot et al. (1985), while Bea et al. (2006) claimed that the dominant population of $483 \pm 3$ Ma crystals reveals the true age of a granitoid produced by melting of Panafrican source. Using the U-Th data of Bea et al. (2006), it appears that the $483 \pm 3$ Ma concor- 


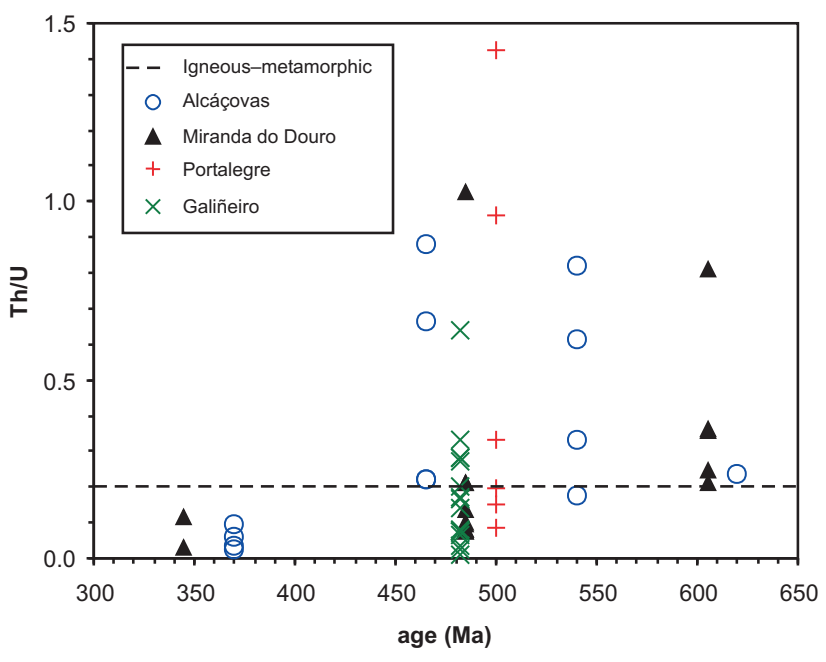

Fig. 1. Th/U ratios vs. radiometric ages in Iberian orthogneisses. Dashed line: boundary line separating disturbed metamorphic compositions $(\mathrm{Th} / \mathrm{U}<0.2)$ from undisturbed igneous compositions $(\mathrm{Th} / \mathrm{U}>0.2)$. Zircon crystals of Portalegre and Galiñeiro orthogneisses, though yielding varying $\mathrm{Th} / \mathrm{U}$ ratios, give the same ages, implying that ages of emplacement and of hydrothermal disturbance are identical within analytical uncertainties. Zircon crystals of Alcóçavas and Miranda do Douro orthogneisses yield igneous compositions and ages of emplacement that differ largely from disturbed compositions and ages of metamorphic overprint. In addition, the distribution of igneous ages in the Alcóçavas orthogneiss reveals an occurrence of older inherited cores.

dant crystals yield non-igneous $\mathrm{Th} / \mathrm{U}$ ratios lower than 0.21 (down to 0.07 ), with only one crystal having high $\mathrm{U}$ and Th contents (808 ppm and $828 \mathrm{ppm}$, respectively) and $\mathrm{Th} / \mathrm{U}$ ratio as high as 1.02 . On the contrary, the 605 $\pm 13 \mathrm{Ma}$ concordant crystals yield igneous $\mathrm{Th} / \mathrm{U}$ ratios consistently higher than 0.21 (Fig. 1). It is suggested here that the Miranda do Douro orthogneiss was derived from an Ediacaran protolith, which underwent hydrothermal alteration by fluids issued from Early Ordovician A-type dykes and sills that are known throughout the Ollo de Sapo domain and are related to the Galiñeiro igneous episode (Floor 1974; Lancelot et al. 1985).

\subsection{Relevance of A-type orthogneisses in geodynamic reconstructions}

A-type igneous suites can be recognized fairly well, if, after their emplacement and cooling, they were not subsequently deformed and metamorphosed. The A-type orthogneiss issue is critical for two reasons: (i) the original bulk-rock and mineral compositions can be obscured by hydrothermal alteration promoted by fluids percolating within the shear zones, (ii) the exact age of igneous emplacement can be erased within the isotopic clocks.

The geological record can provide some help. Withinplate settings can be recognized from sedimentary forma- tions evidencing rifting or passive margin regimes during their deposition. Associated orthogneisses are ascribed to A-type igneous episodes, even if their compositions do not fulfil the required criteria. Accurate radiometric age determinations are necessary, as both inheritance and isotopic resetting may result in dates that are difficult to interpret correctly.

Granitoids and orthogneisses occupy large areas of the basement of the Variscan-Alpine Europe. Careful examination of chemical and isotopic data on undeformed granitoids as well as on orthogneisses provides an evidence of discrete A-type igneous events. Though pieces of older A-type igneous provinces can be preserved, major igneous events took place frequently since the Neoproterozoic and are still going on in the Mediterranean area (Tab. 1).

\section{Periodic A-type granite events within the Variscan-Alpine Europe: an over- view}

Though not voluminous compared with the other granite types, A-type granites substantiate post-collisional (post-orogenic) and anorogenic geodynamic settings. Their emplacement ages span a large time interval, from Neoproterozoic (c. $600 \mathrm{Ma})$ to Triassic (c. $230 \mathrm{Ma})$. The intrusive ages are not randomly distributed, however, and correspond to discrete critical episodes. This will be illustrated by a roughly $\mathrm{N}-\mathrm{S}$ geotraverse. The occurrences described hereafter are listed in Tab. 3.

\subsection{The Central Europe geotraverse}

The Variscan-Alpine Europe is essentially made up of slices of continental and oceanic terranes that were squeezed between the big old continents of Laurentia, Baltica and Gondwana during the Palaeozoic. The terminology used hereafter is extracted from Stampfli and Borel (2004) ${ }^{1}$. The geotraverse considered here comprises the southern margin of Laurentia, the Eastern Avalonia Superterrane and the Hunic Superterrane, which includes the Armorican Terrane Assemblage (ATA). Names of stages, epochs and periods follow hereafter the very last definitions of the IUGS International Commission of Stratigraphy (Ogg et al. 2008).

\footnotetext{
Constantly updated versions of paleogeographic maps are available at: http://www.unil.ch/igp/page22636.html Other useful world-scale maps can be consulted at: http://www.scotese.com/earth.htm and http://jan.ucc.nau.edu/rcb7/ RCB.html
} 


\subsection{The Laurentian margin}

The southern margin of Laurentia in Scotland is composed of a Lewisian foreland, or Hebridean Terrane, bordered by a collage of narrow (c. $50 \mathrm{~km}$ wide) terranes (Oliver et al. 2008 and references therein). The Northern Highland and Grampian terranes, delimited by the Moine Thrust, the Great Glen Fault and the Highland Boundary Fault, yield Proterozoic basements. The Midland Valley and Southern Upland terranes, bordered by the Highland Boundary Fault, the Southern Upland Fault and the Iapetus Suture, represent Early Palaeozoic island arcs and accretionary prisms including remnants of oceanic crust (Ballantrae ophiolite). Ediacaran, Ordovician and Silurian A-type granites occur within the northern continental terranes (Oliver et al. 2008). Early Carboniferous A-type basalt-rhyolite-trachyte igneous suites are mostly exposed within the southern island arc terranes.

The Ediacaran massifs (Older Granites, according to the terminology of Barrow 1893) yield U-Pb zircon ages ranging from $601 \pm 4 \mathrm{Ma}$ to $588 \pm 8 \mathrm{Ma}$, substantiating a fairly short-lived event. Metagranite augen gneisses include riebeckite-bearing peralkaline types and constitute, with coeval $601 \pm 4$ Ma metabasalt-keratophyre formations, a bimodal igneous suite. Isotopic ratios (summary in Steinhoefel et al. 2008) are variable, with $\varepsilon_{\mathrm{Nd}}(\mathrm{t})$ ranging from -6.3 to -4.3 in A-type metagranite and to +4 in metavolcanic rocks, precluding a single homogeneous source, $\delta^{18} \mathrm{O}$ of $8-9 \%$ and high initial ${ }^{87} \mathrm{Sr} /{ }^{86} \mathrm{Sr}(>0.710)$, due to $\mathrm{Rb}$-Sr disturbance during metamorphism and deformation. The 601-588 Ma old bimodal rift-related igneous suite was classically assigned to Rodinia breakup (Soper 1994). This interpretation is at odds with the recent synthesis issued from IGCP 440 (Li et al. 2008), in which the Rodinia supercontinent was subjected to discrete rifting events, prior to the onset of continental disruption at 740 Ma. From the 600 Ma period of time onwards, Rodinia was already broken-up, whereas Scottish Laurentia was bordered by a passive margin created by Iapetus Ocean drifting (see Fig. 9j in Li et al. 2008).

The Ediacaran A-type massifs were metamorphosed and deformed during two discrete episodes forming the Caledonian orogeny, namely the $c .470 \mathrm{Ma}$ Grampian and the c. $430 \mathrm{Ma}$ Scandian events (Oliver 2001). The Grampian event is related to 'hard' collision (Oliver et al. 2008) of Laurentia with the southern island arc terranes and its age is bracketed between the Floian (Mid Arenig), based on $473 \pm 2$ Ma emplacement age of a S-type Newer Granite, and the Darriwilian (Late Arenig), based on 466 \pm 3 Ma cooling ages. No A-type granites are known from that period of time.

Between the Grampian and Scandian events, after a 12 My pause, S-type granites were emplaced between 457 $\pm 1 \mathrm{Ma}$ and $451 \pm 4 \mathrm{Ma}$ in the Grampian Terrane, under extensional regime inducing crustal thinning and erosion rate of about $1.4 \mathrm{~mm} \cdot \mathrm{a}^{-1}$. In the Northern Highland Terrane, only one alkaline igneous event is displayed by the $456 \pm 5 \mathrm{Ma}$ (Sandbian-Katian boundary) Glen Dessary syenite (van Breemen et al. 1979). Isotopic characteristics $\left(\varepsilon_{\mathrm{Nd}}(\mathrm{t})\right.$ varying from +1 to $+4,{ }^{87} \mathrm{Sr} /{ }^{86} \mathrm{Sr}_{\mathrm{i}}=0.7041 \pm$ $0.0001, \delta^{18} \mathrm{O}$ of $5.5-7.5 \%$ ), fractionated concave-upward REE patterns and $\mathrm{Nb}-\mathrm{Ti}$ troughs require an amphibolebearing upper mantle source of probable lithospheric origin (Halliday et al. 1987).

After a 20 My gap, the Scandian event corresponds to flat thrusting of the Northern Highland Terrane onto the Hebridean Terrane to the north and 'soft' collision of the extended Laurentian margin, comprising the Grampian to Southern Upland terranes, with Avalonia to the south (Oliver et al. 2008). It is marked by the emplacement of numerous and voluminous Newer Granite massifs from the Middle Silurian to the Middle Devonian. A-type igneous suites were emplaced coevally with the Newer Granites in the continental terranes.

Within the Northern Highland Terrane, syenite complexes aligned along the Moine Thrust Zone yield emplacement ages from $439 \pm 4 \mathrm{Ma}$ (Loch Ailsh) to $426 \pm$ $9 \mathrm{Ma}$ (Loch Loyal), indicating a Llandovery-Wenlock short-lived magmatic episode (Halliday et al. 1987). Their ages constrain the timing of the ductile to brittle transition along the Moine Thrust Zone. Independently acquired phengite-feldspar $\mathrm{Rb}-\mathrm{Sr}$ data indicate a longlasting episode of brittle deformation from $437 \pm 5 \mathrm{Ma}$ to $408 \pm 6 \mathrm{Ma}$, covering the Silurian and the Early Devonian (Freeman et al. 1998). Syenites are either slightly older than, or roughly coeval with, the famous high-Ba$\mathrm{Sr}$ ("HiBaSr") alkali-calcic granites. The igneous suite comprises mafic rocks, silica-saturated to undersaturated syenites and felsic peralkaline (grorudite) dykes. Isotopic data, i.e. $\varepsilon_{\mathrm{Nd}}(\mathrm{t})$ varying from 0 to $-8,{ }^{87} \mathrm{Sr} /{ }^{86} \mathrm{Sr}_{\mathrm{i}}$ of $0.7045-0.7065$ and $\delta^{18} \mathrm{O}$ of $8.1-10.0 \%$, plot along the Caledonian Parental Magma Array (CPMA) defined by two, depleted and enriched, mantle end-members (Fowler et al. 2008 and references therein).

Within the Grampian Terrane, scarce A-type granite massifs and dykes include biotite \pm amphibole-bearing subsolvus and hypersolvus types. Published ages (Oliver et al. 2008) ranging from $408 \pm 5 \mathrm{Ma}$ to $406 \pm 5 \mathrm{Ma}$ indicate a short-lived Early Devonian episode. They are younger than the $415 \pm 3 \mathrm{Ma}$ (Lochkovian) ultimate stage displayed by the Etive dyke swarm within the famous Glen Coe Complex (Morris et al. 2005). Geochemical features (Steinhoefel et al. 2008) include high LILE and HFSE contents, low $\mathrm{Ba}, \mathrm{Sr}$ and Eu contents, poorly fractionated REE patterns, with unfractionated patterns showing the tetrad effect. The $\varepsilon_{\mathrm{Nd}}(\mathrm{t})$ vary from -2.1 to 6.9 , in the same range as the Caledonian array defined in the Northern Highland Terrane. 
No Ordovician-Silurian A-type igneous suites are exposed in the southern Midland Valley and Southern Upland island arc terranes that are located close to the Iapetus Suture. By contrast, they occur as large lava sheets erupted during the Early Carboniferous and filling the Midland Valley (Francis 1983). The greatest volume, up to $6000 \mathrm{~km}^{3}$, was produced during the TournaisianVisean in the form of lava flows, of which c. $85 \%$ were mildly silica-undersaturated basalts. The other formations consist of silica-undersaturated and saturated trachytic and rhyolitic differentiates, which were mostly erupted at c. $345 \mathrm{Ma}$ (Tournaisian-Visean boundary). After the Visean, only basalts and basanites were emitted with no felsic differentiates.

\subsection{Eastern Avalonia}

Avalonian terranes constitute a long ribbon extending from eastern North America to southeastern Europe. They are commonly subdivided into Western Avalonia, located now in the North American continent, and Eastern Avalonia, covering in Europe a large area from Ireland-England to north-central Europe to Eastern Carpathians-Moesia. The Proterozoic continental basement crops out in Poland and Czech Republic, whereas the Early to Middle Palaeozoic sedimentary cover is developed in Belgium and Germany.

The Proterozoic continental basement is exposed in Poland and Czech Republic or known from boreholes (Jelínek and Dudek 1993). Despite a great complexity due to numerous boundary faults, terranes of Avalonian affinities, i.e. made up of Neoproterozoic high-grade metamorphic rocks unconformably overlain by a Devonian-Carboniferous envelope, can be recognized (Oliver et al. 1993). Among them, the Brunovistulian Terrane, including its Moravo-Silesian metamorphic counterparts (Kalvoda et al. 2008 and references therein) occupies the eastern Bohemian Massif and the Eastern Sudetes. The timing of collage of these terranes onto Baltica is still debated (for contrasting views, see Mazur et al. 2006; Nawrocki and Poprawa 2006). Orthogneisses interleaved with paragneisses and amphibolites yield Ediacaran to Cambrian ages (Oliver et al. 1993). Non-A-type Strzelin-Nowolesie orthogneisses, SW Poland, have zircon crystals with older inherited cores, igneous rims at 600 $\pm 7 \mathrm{Ma}$ and metamorphic overgrowths at $568 \pm 7 \mathrm{Ma}$ (Oberc-Dziedzic et al. 2003). The latter age is reminiscent of the $567 \pm 5 \mathrm{Ma}$ igneous age of A-type metagranite exposed as small massifs within the c. 600-580 Ma Thaya Batholith, Austria (Friedl et al. 2004). These Ediacaran ages correspond to post-orogenic processes occurring after the Cadomian orogeny. A-type Gosciecice and Stachów-Henryków orthogneisses, SW Poland, yield, respectively, igneous ages of $504 \pm 1 \mathrm{Ma}$ and $500 \pm 5 \mathrm{Ma}$
(Drumian-Guzhangian) (Oberc-Dziedzic et al. 2005), coeval to the beginning of Rheic Ocean drifting. A-type metagranites, carrying both hypersolvus (Rudná-type) and subsolvus (Polanka-type) alkali feldspar assemblages, occur as yet undated small masses within the Desná Unit, Czech Republic. A Carboniferous age was assumed on the basis of too low ${ }^{87} \mathrm{Sr} /{ }^{86} \mathrm{Sr}$ ratios corrected to Ediacaran times (Hanžl et al. 2007), but this is questionable for low-grade cataclastic rocks (see above). In any case, high $\mathrm{Nd}$ isotopic ratios indicate juvenile magmas.

Early Paleozoic rocks are rare, only one basalt vein was dated by K-Ar at $438 \pm 16 \mathrm{Ma}$ (Llandovery), substantiating Silurian igneous activity. Cooling ages of 487-420 Ma recorded by detrital white mica and monazite occurring within Devonian-Carboniferous sedimentary formations document, however, an important igneous and/or thermal activity in the source area during the Ordovician-Silurian period (Kalvoda et al. 2008). The Devonian Moravo-Silesian Basin is filled up with Emsian-Famennian shallow marine sedimentary formations and submarine to subaerial volcanic formations. Two discrete belts are distinguished (Janoušek et al. 2006). The western belt is characterised by abundant metasediments accompanied by submarine basic-intermediate calc-alkaline volcanites, with subordinate felsic types, suggesting a volcanic-arc setting above a subduction zone. The eastern belt displays abundant, partly subaerial, alkali basalt-A-type rhyolite volcanic suite, with a high proportion of Frasnian felsic products and dykes (rhyolite-comendite-pantellerite) crosscutting the Proterozoic basement. Late tholeiitic dolerite dykes and sills complete the igneous association. The within-plate settings indicate a continental passive margin subjected to extensional regime, perhaps under the influence of a nearby subduction zone (Patočka and Valenta 1996). As the Devonian basins within the Brunovistulian Terrane seem to have rotated c. $90^{\circ}$ clockwise at the Devonian-Carboniferous boundary, the original orientation of the volcanic belts and the sedimentary basins should have been $\mathrm{E}-\mathrm{W}$, but their exact configuration remains unclear.

In Germany, Eastern Avalonia consists of inliers covered by the Mesozoic-Cenozoic sedimentary cover. It comprises the Rheno-Hercynian Zone (Kossmat 1927) and exotic terranes, including the Harz Mountains. From contradictory statements in etymological dictionaries, it appears that the classical term "Hercynian" could either come from, or be the origin for, the name of Harz, which formed a part of the larger Hercynian Forest described in the Antiquity. The Rheno-Hercynian Zone in Belgium and Germany is characterized by plateaux dissected by river valleys, among which the "Rheinisches Schiefergebirge" exposes autochthonous folded-faulted Palaeozoic sedimentary series, overthrusted by Giessen-Harz Nappe and other allochthonous slices. Autochthonous units rep- 
resent the sedimentary cover of the former southern passive margin of Avalonia facing the Rheic Ocean, whereas allochthonous units are composed of dismembered oceanic flysch basins formed during the progressive Rheic oceanic closure (Huckriede et al. 2004).

No basement formations older than Devonian are exposed within the "Rheinisches Schiefergebirge". The autochthonous sedimentary series comprises Devonian deltaic, shallow and deep marine sequences, with local development of reefs, and Lower Carboniferous turbidites. Within-plate igneous activity is documented by Devonian (Flick et al. 2008) and Carboniferous (Salamon et al. 2008) volcanic events. The first Givetian-Frasnian event consists of 389-384 Ma episodes dated by conodont zones. It involved submarine eruptions of basanite-alkali basalt-trachyandesite pillow lavas and hyaloclastites forming large seamounts. Emerged islands display additional trachyte and A-type rhyolite lava flows, pyroclastites and domes. Subsequent events erupted only submarine mafic products, i.e. Famennian primitive basanites-alkali basalts, Tournaisian-Visean tholeiitic picrites-basalts and, ultimately, Visean primitive alkali basalts crowded with xenoliths of possible upper mantle origin, and no felsic differentiates.

Numerous boreholes through the Mesozoic-Cenozoic Northeast German Basin have reached or even perforated a c. $2000 \mathrm{~m}$-thick Late Carboniferous-Early Permian volcanic succession (Benek et al. 1996). Based largely on lithostratigraphic correlations, five episodes, yet undated by radiometric techniques, are documented from the Ghzelian, i.e. slightly before the Carboniferous-Permian boundary, to the Sakmarian-Artinskian boundary. They accompanied extensional settings within the Pangaea super-continent. East Brandenburg yields an enigmatic, presumably Asselian, (trachy-) andesite-(trachy-) dacite magnesian suite that straddles the alkaline-subalkaline boundary in the total alkali-silica diagram (Rickwood 1989 and references therein). Ghzelian-Sakmarian tholeiitic dolerites-basalts, with depleted to enriched MORB-like compositions, are coeval to basalt-trachyandesite-trachyte-A-type rhyolite ferroan alkaline suites and were postdated by Late Sakmarian basanites-trachybasalts. A-type rhyolites, forming up to $70 \%$ of the c. $48000 \mathrm{~km}^{3}$ volume of the Northeast German Basin volcanics, occur as ignimbrites (Benek et al. 1996) or lava domes (Paulick and Breitkreuz 2005). The $\mathrm{U}-\mathrm{Pb}$ zircon igneous ages, bracketed between 300 and $297 \pm 3 \mathrm{Ma}$, substantiate a very short-lived episode close to the Carboniferous-Permian boundary, though dated samples do not cover the entire range of volcanic activity in the Northeast German Basin. The mean extrusion rate was estimated at about $0.01 \mathrm{~km}^{3} \cdot \mathrm{a}^{-1}$, corresponding to a magma production rate in the order of $0.1 \mathrm{~km}^{3} \cdot \mathrm{a}^{-1}$ (Breikreutz and Kennedy 1999). Thermal subsidence in the Northeast German Basin, slow during the Permian, increased abruptly at the Permian-Triassic boundary. The complete absence of post-Permian igneous activity was related to cooling and thickening of the continental lithosphere (Benek et al. 1996).

Allochthonous units display neither Proterozoic nor Early Paleozoic basements. They are essentially made up of metamorphosed Devonian-Carboniferous sedimentary units, with very few occurrences of metabasalts. Detrital zircon grains yield dominant Precambrian and rare Silurian-Early Devonian igneous, not metamorphic ages, implying that the sedimentation never took place before $410 \pm 10 \mathrm{Ma}$ (Geisler et al. 2005). Pelagic sediments are associated with turbidites, like the non-metamorphosed successions observed in autochthonous units. The Giessen-Harz Nappe contains N-MORB tectonic slices overlain by extremely condensed Devonian radiolarian cherts and pelagic shales, implying an oceanic provenance (Huckriede et al. 2004). A-type granite complexes and the coeval Harzburg layered igneous body, which the term "harzburgite" comes from, are exposed in the Harz Mountains, or were drilled near Flechtingen (Baumann et al. 1991, Förster and Tischendorf 1996). In the Flechtingen inlier, a bimodal trachyandesite-rhyolite igneous suite was emplaced as sills and ignimbritic sheets (Breitkreuz and Kennedy 1999). The U-Pb zircon igneous ages of $302 \pm 3 \mathrm{Ma}$ (ignimbrite), $295 \pm 1 \mathrm{Ma}$ (Oker granite), $294 \pm 1 \mathrm{Ma}$ (Harzburg gabbronorite) and $293 \pm 3 \mathrm{Ma}$ (Brocken granite) with K-Ar biotite cooling ages of 298 $\pm 5 \mathrm{Ma}$ (Flechtingen granite) and $296 \pm 10 \mathrm{Ma}$ (Ramberg granite) document again a short-lived episode close to the Carboniferous-Permian boundary, in agreement with the U-Pb zircon $296 \pm 1 \mathrm{Ma}$ and titanite $295 \pm 1$ Ma cooling ages recorded in hornfels aureoles. Major- and trace-element compositions indicate A-type post-orogenic settings (for a review, see Förster and Tischendorf 1996).

\subsection{The Armorican Terrane Assemblage}

The Armorican Terrane Assemblage (ATA) is a part of the Hunic Superterrane (Stampfli et al. 2004). It occupies a nearly $1000 \mathrm{~km}$-wide area throughout central and southern Europe and is bordered to the south by tectonic units (Rif, Kabylies) overthrusted onto the North African Gondwana shelf during Neogene times (Jolivet and Faccenna 2000). The current configuration differs strongly from the original setting, because the Armorican Terrane Assemblage was dismembered and recomposed by wrench and transcurrent shear zones.

A-type igneous suites exposed in Alpine-related realms have been reviewed elsewhere (Bonin et al. 1998 and references therein). The most voluminous suites were emplaced well after Pangaea welding and predate continental break-up and Neo-Tethys Ocean development 
during the Mesozoic. Corsica provides a unique example yielding two discrete igneous episodes separated by a period of quiescence. The first was Permian at $275 \pm 10 \mathrm{Ma}$ (Artinskian-Wordian) and the second Triassic at $245 \pm 10$ Ma (Induan-Anisian), followed ultimately by a thermal event at c. $200 \mathrm{Ma}$ (Triassic-Liassic boundary) (Bonin et al. 2008, and references therein). Silica-oversaturated to undersaturated complexes, e.g., Monzoni-Predazzo and Karavanken in Southern Alps, Ditrãu in Eastern Carpathians, yield Ladinian (c. 237-232 Ma) ages.

Such a sequence is unknown in the ATA that was unaffected by Alpine tectonics. The Mid-German Crystalline Zone and the Saxo-Thuringian Zone will be reviewed hereafter. The Mid-German Crystalline Zone (MGCZ) constitutes a SW-NE trending belt of crystalline rocks that are exposed in various inliers in Pfalz and form the massifs of Odenwald, Spessart, Ruhla and Kyffhäuser. The MGCZ was penetrated by drill holes in the Saar-Nahe Basin and other sedimentary troughs to the $\mathrm{NE}$ and could extend southwestwards to Cornwall (Dörr et al. 1999) and even Spain. It is currently considered as a part of the Rheic suture zone between the Eastern Avalonia and the Saxo-Thuringian Zone, which belongs to the ATA.

Post-Cambrian metasedimentary units yield both Gondwana and Baltica affinities (Gerdes and Zeh 2006). Intercalated metabasalts are mainly calc-alkaline with an island-arc signature, whereas MORB signatures are scarce. Such features suggest that the composite terrane could correspond to an accretionary prism close to the suture zone. Early Devonian orthogneisses intercalated with IAB-like metabasalts yield volcanic arc signatures, such as the $413 \pm 5$ and $398 \pm 3$ Ma members of the Central Gneiss Unit, Ruhla (Brätz 2000). From the Devonian-Carboniferous boundary onward, all orthogneissic and metasedimentary formations followed a clockwise P-T-t metamorphic evolution associated to ductile deformation before and during emplacement of post-collisional 360-325 Ma (Tournaisian-Serpukhovian) high-K calcalkaline suites (Reischmann and Anthes 1996; Altherr et al. 1999; Zeh et al. 2005).

A-type igneous suites span the entire Cambrian-Permian range of time. The $489 \pm 1 \mathrm{Ma}$ (Cambrian-Ordovician boundary) Volkach syenite, revealed by drilling east of Spessart, yields the oldest age (Anthes and Reischmann 2001) and a Bulk Silicate Earth (BSE) isotopic signature (Anthes 1998); it was coeval to Rheic Ocean development. Late Silurian alkali-calcic orthogneisses of A-type affinities include the $426 \pm 4$ Ma Silbergrund gneiss and the $423 \pm 6$ Ma Erbstrom gneiss, Ruhla (Brätz 2000), the $418 \pm 18$ Ma Rotgneiss (Okrusch and Richter 1986) and the $410 \pm 18$ Ma Haibach gneiss, Spessart (Dombrowski et al. 1995). Early Devonian alkali-calcic A-type orthogneisses comprise the $405 \pm 3$ Ma Böllstein orthogneiss,
Odenwald (Reischmann et al. 2001), and the $400 \pm 4 \mathrm{Ma}$ Steinbach augen gneiss, Ruhla (Brätz 2000). All igneous suites were emplaced in a continental area experiencing tensional regimes and located far from the active margin of the ATA. The c. 344 Ma (Visean) Darmstadt albite granite, Odenwald, is unique during the Early Carboniferous, with its A-type composition and a BSE isotopic signature (Anthes 1998).

A short-lived within-plate igneous episode at the Carboniferous-Permian boundary is documented by trachybasalt-trachydacite-A-type rhyolite igneous suites of the Halle Volcanic Complex (Romer et al. 2001) and the Saar-Nahe Basin as well as by the plutonic suite of the Ruhla inlier (Zeh and Brätz 2002). A-type rhyolite occurs as laccolith units (Breitkreuz and Mock 2004) emplaced in discrete pulses from the Middle Pennsylvanian to the Sakmarian at $307 \pm 3 \mathrm{Ma}, 301-298 \pm 3 \mathrm{Ma}$ and $294 \pm$ 3 Ma (Breitkreuz and Kennedy 1999). Intense volcanic activity, with magmas ranging from basalt to trachyte and A-type rhyolite, took place in the Saar-Nahe Basin during the 296-293 Ma (Asselian-Sakmarian) period of time. Intrusions, extrusions, diatremes, lava flows and ignimbrites are exposed in a half-graben bounded to the north by a detachment fault parallel to the Avalonia-Armorica plate boundary (for a review, see Lorenz and Haneke 2004). As shown by major- and trace-element whole-rock chemical data (Brätz 2000), the Ruhla plutonic suite, emplaced under a transcurrent ductile-brittle shear regime, includes a monzonite-syenite feldspar cumulate body (the so-called Trusetal granite), monzodiorite (Brotterode diorite), Atype granites (Ruhla and Eselsprung granites) and granite porphyry dykes. Intrusive episodes yield mean ages of c. $305 \mathrm{Ma}$ (Eselsprung granite, Brätz 2000), $301 \pm 5 \mathrm{Ma}$ (Trusetal granite), $295 \pm 5 \mathrm{Ma}$ (Ruhla granite and granite porphyry dykes), $289 \pm 5 \mathrm{Ma}$ (Brotterode diorite) and 285 $\pm 5 \mathrm{Ma}$ to $277 \pm 7 \mathrm{Ma}$ (late granite porphyry dykes), in agreement with field evidence and Ar-Ar cooling ages in the metamorphic country rocks (Zeh et al. 2000).

The Saxo-Thuringian Zone represents a continental part of the ATA. In Saxony and Thuringia, each of them representing a locus typicus defining the Saxo-Thuringian Zone, A-type granite suites are fairly well represented during the Paleozoic. In the external domain, the Vesser MOR-related complex comprises a basalt $(508 \pm 2 \mathrm{Ma})$ - dacite (497 $\pm 2 \mathrm{Ma})$ - rhyolite volcanic suite, associated with a $502 \pm 2$ Ma tholeiitic gabbro-dolerite. The nearby Ediacaran sedimentary assemblages were intruded by a c. $490 \mathrm{Ma}$ (Furongian) granite (Linnemann et al. 2007). In the internal domain, they are cut by $490 \pm 3 \mathrm{Ma}$ (Furongian) to $485 \pm 6 \mathrm{Ma}$ (Tremadocian) granites and covered unconformably by two episodes of $487 \pm 5 \mathrm{Ma}$ (Cambrian-Ordovician boundary) rhyolitic pyroclastic units and $479 \pm 5 \mathrm{Ma}$ (Tremadocian-Floian) porphyroid (Linnemann et al. 2007). During the Carboniferous, 
contrasting igneous suites emplaced under shear stress regimes that changed abruptly from the $340-330 \mathrm{Ma}$ (Visean) high-K Meissen granite association, related to dextral strike-slip movement of the Elbe Fault Zone, to the $327 \pm 4 \mathrm{Ma}$ (Visean-Serpukhovian boundary) Markersbach A-type granite, showing no strike-slip influence (Hofmann et al. 2008). This A-type Li-mica-bearing granite (Förster and Tischendorf 1996; Förster 2001) shares the same A-type affinities with the Sudetic 319-314 \pm 4 Ma Karkonosze and $309 \pm 2$ Ma Strzegom-Sobotka granite massifs, as well as bimodal trachybasalt-trachyandesite-trachydacite-rhyolite volcanic suite (Mazur et al. 2007). Younger volcanic activity took place at the Carboniferous-Permian boundary, as shown by the 308 $\pm 1 \mathrm{Ma}$ Teplice-Altenberg rhyolitic caldera (Förster et al. 1995), the younger, yet undated, Zinnwald-Cínovec zinnwaldite-albite granite and the $297 \pm 8$ Ma rhyolite dykes within the Eibenstock Pluton (Kempe et al. 2004). Later on, two eruptive episodes are documented in the Lower Rotliegend molasse of the Saxonian Sub-Erzgebirge Basin. A pyroxene quartz porphyry yielded an age of $296 \pm 2 \mathrm{Ma}$ (Förster and Tischendorf 1996), and "lower series" rhyolites $278 \pm 5 \mathrm{Ma}$ (Nasdala et al. 1998), substantiating diachronous activity throughout the large intermontane basin.

\section{Summary and conclusions}

A-type granite igneous complexes are fairly abundant within the Variscan-Alpine Europe (Tab. 3). However, discrete ages of emplacement document geodynamic settings varying from post-orogenic, through intra-continental rifting to passive margin tectonic regimes. They thus illustrate a repeated history of continental breakup and oceanic basin development followed by oceanic closure and post-collisional transcurrent displacement.

At the end of the Neoproterozoic, Laurentia developed a passive margin toward the Iapetus Ocean, whereas the Cadomian-Pan-African orogenic episode had its climax within Gondwana at about $600 \mathrm{Ma}$ (Ediacaran). Ediacaran to Early Cambrian A-type granites, occupying pieces of consolidated Gondwana basement, display early anorogenic features associated with the birth of the Rheic Ocean.

The incipient drifting of the Rheic Ocean was followed within the Armorican Terrane Assemblage by a major 485 Ma (Tremadocian) rifting and igneous event characterized by A-type suites now converted into orthogneisses (metagranites), amphibolites (metabasalts) and leptynites (metatrachytes-metarhyolites) in the internal parts of the Variscan belt. The further development of the Rheic

Tab. 3 Representative A-type igneous episodes within the Variscan-Alpine Europe

\begin{tabular}{|c|c|c|c|c|c|c|}
\hline Period & Stage & $\begin{array}{l}\text { Age } \\
\text { (Ma) }\end{array}$ & Laurentian margin & Eastern Avalonia & \multicolumn{2}{|c|}{ Armorican Terrane Assemblage } \\
\hline Triassic & Induan-Anisian & $250-230$ & & & $\begin{array}{c}\text { Corsica } \\
\text { Monzoni-Predazzo } \\
\text { Ditrãu, Romania }\end{array}$ & $\begin{array}{l}\text { Intra-continental } \\
\text { rift }\end{array}$ \\
\hline \multirow{3}{*}{ Permian } & Artinskian-Wordian & $285-265$ & & & $\begin{array}{l}\text { Saar-Nahe Basin, } \\
\text { W Mediterranean } \\
\text { Province }\end{array}$ & $\begin{array}{l}\text { Intra-continental } \\
\text { rift }\end{array}$ \\
\hline & Asselian-Sakmarian & $302-293$ & & $\begin{array}{cc}\text { NE German } & \text { Intra-continental } \\
\text { Basin, Harz } & \text { rift } \\
\end{array}$ & $\begin{array}{l}\text { Halle, Saar-Nahe } \\
\text { basins, Ruhla }\end{array}$ & $\begin{array}{l}\text { Intra-continental } \\
\text { rift }\end{array}$ \\
\hline & Serpukhovian-Moscovian & $327-309$ & & & Saxo-Thuringian & $\begin{array}{c}\text { Intra-continental } \\
\text { rift }\end{array}$ \\
\hline Carboniferous & Tournaisian & 345 & $\begin{array}{|cc|}\text { Midland } & \text { Intra-continental } \\
\text { Valley } & \text { rift } \\
\end{array}$ & & & \\
\hline \multirow{2}{*}{ Devonian } & Givetian-Frasnian & 389-384 & & $\begin{array}{cc}\text { Rheinisches } & \text { Rheic Ocean } \\
\text { Schiefergebirge } & \text { passive margin }\end{array}$ & & \\
\hline & Pragian & $408-400$ & Grampian $\begin{array}{c}\text { Post-Scandian } \\
\text { episode }\end{array}$ & & $\begin{array}{c}\text { Mid-German } \\
\text { Crystalline Rise }\end{array}$ & $\begin{array}{c}\text { Intra-continental } \\
\text { rift }\end{array}$ \\
\hline \multirow{2}{*}{ Silurian } & Telychian-Lochkovian & $426-410$ & & & $\begin{array}{c}\text { Mid-German } \\
\text { Crystalline Rise }\end{array}$ & $\begin{array}{c}\text { Intra-continental } \\
\text { rift }\end{array}$ \\
\hline & Llandovery-Wenlock & $440-426$ & $\begin{array}{l}\text { Moine } \\
\text { Thrust }\end{array}$ Scandian episode & & & \\
\hline \multirow[b]{2}{*}{ Ordovician } & Sandbian-Katian & 456 & $\begin{array}{|cc|}\text { Northern } & \text { Post-Grampian } \\
\text { Highland } & \text { episode }\end{array}$ & & & \\
\hline & Furongian-Tremadocian & $490-480$ & & & $\begin{array}{c}\text { Mid-German } \\
\text { Crystalline Rise, } \\
\text { Saxo-Thuringian }\end{array}$ & $\begin{array}{l}\text { Rheic Ocean } \\
\text { passive margin }\end{array}$ \\
\hline Cambrian & Epoch 3 & 508-497 & & $\begin{array}{c}\text { Rheic Ocean } \\
\text { drifting }\end{array}$ & Saxo -Thuringian & $\begin{array}{c}\text { Rheic Ocean } \\
\text { drifting }\end{array}$ \\
\hline \multirow{2}{*}{ Neoproterozoic } & Ediacaran & $570-560$ & & $\begin{array}{cc}\text { Thaya, Austria } & \begin{array}{c}\text { Post-Cadomian } \\
\text { episode }\end{array}\end{array}$ & & \\
\hline & & $601-588$ & $\begin{array}{|cc|}\text { Older } & \text { Iapetus passive } \\
\text { Granites } & \text { margin }\end{array}$ & & & \\
\hline
\end{tabular}


Ocean led to Avalonia-Laurentia collision postdated by A-type igneous episodes in Scotland. In addition, the Late Ordovician to Early Carboniferous period was marked by alkaline igneous episodes at the passive margin of Avalonia, whereas the active margin of the Armorican Terrane Assemblage was devoid of any A-type igneous events.

The Variscan collision was followed in the Armorican Terrane Assemblage by discrete post-orogenic episodes, namely 350-340 Ma (Tournaisian), $320 \mathrm{Ma}$ (Serpukhovian) and $300 \mathrm{Ma}$ (Ghzelian) igneous events. The 300 Ma event, widespread throughout the Variscan-Alpine Europe, constituted a climactic igneous event affecting both Avalonia and Armorican Terrane Assemblage.

Early to Middle Permian (280-260 Ma) and Late Permian to Early Triassic (250-230 Ma) A-type provinces were emplaced in the southernmost parts of the Variscan-Alpine Europe. They accompanied incipient Pangaea breakup and heralded the future birth of the Neo-Tethys Ocean, which started by the 200 Ma Central Atlantic Large Igneous Province.

A-type granite events provide space and time clues to discrete Ediacaran to Triassic episodes, during which Pannotia broke up, Gondwanan terranes were amalgamated onto Baltica and, ultimately, Pangaea broke up. They identify waning orogenic stages, corresponding to orogenic belt collapse, transcurrent movements along transform fault zones and subsequent peneplanation, as well as pre- to early oceanic stages, corresponding to extensional reactivation of shear zones, incipient rifting and passive margin development. Their occurrences are, therefore, especially helpful for recognition of terrane boundaries and palinspatic reconstructions.

Acknowledgements. This is a contribution to the UNESCO-IGCP Project 510 "A-type granites and related rocks through time", chaired by Roberto Dall'Agnol and led jointly by Carol Frost, Tapani Rämö and Laurence Robb. Vojtěch Janoušek prompted me to submit this paper to the Special Issue of the Journal of Geosciences on "Field, analytical and experimental approaches to silicic magmatism in collisional orogens" and I am indebted to him for his patience. The considerations presented here on the evolution of Variscan Germany stem from observations and discussions made during the field trip Frankfurt-Dresden, managed by Peter Königshof, Ulf Linnemann and Armin Zeh, following the UNESCOIGCP Projects 497-499 Joint Conference held at Frankfurt in October 2008. The whole party is thanked for judicious remarks and information, but should not be held responsible for any misconceptions and prejudices that remain my own. Many thanks are due to the anonymous reviewer and David Dolejš, the handling editor, who both gave quick critical assessments of the first version and were of great help in improving the paper.

\section{References}

Altherr R, Henes-Klaiber U, Hegner E, Satir M, Langer C (1999) Plutonism in the Variscan Odenwald (Germany): from subduction to collision. Int J Earth Sci 88: 422-443

Anthes G (1998) Geodynamische Entwicklung der Mitteldeutschen Kristallinschwelle: Geochronologie und Isotopengeochemie. Unpublished Ph.D. Thesis, Johannes Gutenberg-Universität Mainz, pp 1-154

Anthes G, Reischmann T (2001) Timing of granitoid magmatism in the eastern mid-German crystalline rise. J Geodyn 31: 119-143

Baumann A, Grauert B, Mecklenburg S, Vinx R (1991) Isotopic age determinations of crystalline rocks of the Upper Harz Mountains, Germany. Geol Rundsch 80: 669-690

Bea F, Montero P, Talavera C, Zinger T (2006) A revised Ordovician age for the Miranda do Douro orthogneiss, Portugal. Zircon U-Pb ion-microprobe and LA-ICPMS dating. Geol Acta 4: 395-401

Bendaoud A, Ouzegane K, Godard G, Liégeois JP, Kienast JR, Bruguier O, Drareni A (2008) Geochronology and metamorphic P-T-X evolution of the Eburnian granulite-facies metapelites of Tidjenouine (Central Hoggar, Algeria): witness of the LATEA metacratonic evolution. In: ENNIH N, LiÉGEOIS JP (eds) The Boundaries of the West African Craton. Geol Soc London Spec Pub 297: pp 111-146

Benek R, Kramer W, McCann T, Scheck M, Negendank JFW, Korich D, Huebscher HD, Bayer U (1996) PermoCarboniferous magmatism in the Northeast German Basin. Tectonophysics 266: 379-404

BiLlings MP (1945) Mechanics of igneous intrusion in New Hampshire. Amer J Sci 243-A: 40-68

Black R, LAmeyre J, Bonin B (1985) The structural setting of alkaline complexes. J Afr Earth Sci 3: 5-16

Bonin B (2007) A-type granites and related rocks: evolution of a concept, problems and prospects. Lithos 97: 1-29

Bonin B, Bebien J (2005) The granite-upper mantle connection in terrestrial planetary bodies: an anomaly to the current granite paradigm? Lithos 80: 131-145

Bonin B, Azzouni-Sekkal A, Bussy F, Ferrag S (1998) Alkali-calcic and alkaline post-orogenic (PO) granite magmatism: petrologic constraints and geodynamic settings. Lithos 45: 45-70

Bonin B, Bebien J, Masson P (2002) Granite: a planetary point of view. Gondwana Res 5: 261-273

Bonin B, Platevoet B, Poitrasson F, Renna MR (2008) The Permian-Triassic A-type volcanic-plutonic igneous suite of Corsica. Eurogranites - IGCP 5102008 Joint Field-Meeting, field guide, pp 1-54

Bowen NL (1928) The Evolution of Igneous Rocks. Princeton University Press, Princeton, pp 1-334 
BRÄTz H (2000) Radiometrische Altersdatierungen und geochemische Untersuchungen von Orthogneisen, Graniten und Granitporphyren aus dem Ruhlaer Kristallin, Mitteldeutsche Kristallinzone. Unpublished Ph.D. Thesis, Bayerische Julius-Maximilians-Universität Würzburg, pp 1-151

Breitkreuz C, Kennedy A (1999) Magmatic flare-up at the Carboniferous/Permian boundary in the NE German Basin revealed by SHRIMP zircon ages. Tectonophysics 302: 307-326

Breitkreuz C, Mock A (2004) Are laccolith complexes characteristic of transtensional basin systems? Examples from the Permo-Carboniferous of Central Europe. In: Breitkreuz C, Petford N (eds) Physical Geology of High-level Magmatic Systems. Geol Soc London Spec Pub 234: pp 13-31

Bussy F, SARTori M, Thelin P (1996) U-Pb zircon dating in the middle Penninic basement of the Western Alps (Valais, Switzerland). Schweiz Mineral Petrogr Mitt 76: $81-84$

Clarke DB (1996) Two centuries after Hutton's 'Theory of the Earth': the status of granite science. Trans Roy Soc Edinb, Earth Sci 87: 353-359

Cordani UG, Nutman AP, Andrade AS, Santos JF, Azevedo MDR, MENDEs MH, PinTo MS (2006) New U-Pb SHRIMP zircon ages for pre-Variscan orthogneisses from Portugal and their bearing on the evolution of the Ossa-Morena Tectonic Zone. Anais Acad Brasil Ciências 78: 133-149

Dombrowski A, Henjes-Kunst F, Höhndorf A, Kröner A, OKrusch M, Richter P (1995) Orthogneisses in the Spessart Crystalline Complex, north-west Bavaria: Silurian granitoid magmatism at an active continental margin. Geol Rundsch 84: 399-411

Dörr W, Floyd PA, LeVeridge BE (1999) U-Pb ages and geochemistry of granite pebbles from the Devonian Menaver Conglomerate, Lizard Peninsula: provenance of Rhenohercynian flysch of SW England. Sedim Geol 124: $131-147$

EBy GN (1990) The A-type granitoids: a review of their occurrence and chemical characteristics and speculations on their petrogenesis. Lithos 26: 115-134

Etxebarria M, Chalot-Prat F, Apraiz A, Eguíluz L (2006) Birth of a volcanic passive margin in Cambrian time: rift paleogeography of the Ossa-Morena Zone, SW Spain. Precambr Res 147: 366-386

Flick H, Nesbor D, Königshof P (2008) Volcanism and reef development in the Devonian: a case study from the Rheinisches Schiefergebirge (Lahn syncline, Germany). In: Königshof P, Linnemann U (eds) The Rheno-Hercynian, Mid-German Crystalline and Saxo-Thuringian Zones (Central European Variscides). Final meeting of IGCP 497 and IGCP 499 Excursion Guide, pp 55-78

Floor P (1974) Alkaline gneisses. In: Sørensen H (ed) The Alkaline Rocks. John Wiley \& Sons, London, pp 124-142
FÖRSTER HJ (2001) Synchysite-(Y) - synchysite-(Ce) solid solutions from Markersbach, Erzgebirge, Germany: REE and Th mobility during high-T alteration of highly fractionated A-type granites. Mineral Petrol 72: 259-280

Förster HJ, Seltmann R, Tischendorf G (1995) Highfluorine, low-phosphorous A-type (post collision) silicic magmatism in the Erzgebirge. Terra Nostra 7: 32-34

Förster HJ, Tischendorf G (1996) Compositional heterogeneity of silicic magmatic rocks from the German Variscides. Z geol Wiss 24: 467-482

Fowler MB, Kocks H, Darbyshire DPF, Greenwood PB (2008) Petrogenesis of high Ba-Sr plutons from the Northern Highlands Terrane of the British Caledonian Province. Lithos 105: 129-148

FrANCIS EH (1983) Carboniferous-Permian igneous rocks. In: CRAIG GY (ed) Geology of Scotland, $2^{\text {nd }}$ edition. Scottish Academy Press, Edinburgh, pp 297-324

Freeman SR, Butler RWH, Cliff RA, Rex DC (1998) Direct dating of mylonite evolution: a multi-disciplinary geochronological study from the Moine Thrust Zone, NW Scotland. J Geol Soc, London 155: 745-758

Friedl G, Finger F, Paquette JL, von Quadt A, McNaughton NJ, Fletcher IR (2004) Pre-Variscan geological events in the Austrian part of the Bohemian Massif deduced from U-Pb zircon ages. Int J Earth Sci 93: 802-823

Frost BR, Frost CD (2008) A geochemical classification for feldspathic igneous rocks. J Petrol 49: 1955-1969

Geisler T, Vinx R, Martin-Gombajov N, Pidgeon RT (2005) Ion microprobe (SHRIMP) dating of detrital zircon grains from quartzites of the Eckergneiss Complex, Harz Mountains (Germany): implications for the provenance and the geological history. Int J Earth Sci 94: 369-384

Gerdes A, Zeh A (2006) Combined U-Pb and Hf isotope LA(MC-)ICP-MS analyses of detrital zircons: comparison with SHRIMP and new constraints for the provenance and age of an Armorican metasediment in Central Germany. Earth Planet Sci Lett 249: 47-61

Halliday AN, Aftalion M, Parsons I, Dickin AP, Johnson MRW (1987) Syn-orogenic alkaline magmatism and its relationship to the Moine Thrust Zone and the thermal state of the lithosphere in NW Scotland. J Geol Soc, London 144: 611-617

HanŽl P, JANOUŠEK V, ŽÁčEK V, Wilimský D, Aichler J, Erban V, Pudilová M, Chlupáčová M, Buriánková K, Mixa P, Pecina V (2007) Magmatic history of granite-derived mylonites from the southern Desná Unit (Silesicum, Czech Republic). Mineral Petrol 89: 45-75

Hofmann M, Linnemann U, Gerdes A, Ullrich B (2008) Closure of the Rheic Ocean and the final pulse of the Variscan orogeny in the Bohemian Massif - timing of large-scale strike-slip processes and basement exhumation by LA-ICP-MS U-Pb zircon dating from the Elbe Zone (Saxo-Thuringian Zone, Germany). In: KöNIGSHOF 
P, Linnemann U (eds) From Gondwana and Laurussia to Pangaea: Dynamics of Oceans and Supercontinents. Final Meeting of IGCP 497 and IGCP 499, $20^{\text {th }}$ International Senckenberg-Conference \& $2^{\text {nd }}$ Geinitz-Conference, Abstracts and Programme, pp 53

Janoušek V, Hanžl P, Aichler J, Pecina V, Erban V, Wilimský D, Ž́̇́ček V, Mixa P, Buriánková K, Pudilová M, ChlupéčovÁ M (2006) Contrasting petrogenesis of two volcanic suites in the Devonian Vrbno Group (Hrubý Jeseník Mts., Czech Republic). Geolines 20: 57-59

Jelínek E, Dudek A (1993) Geochemistry of subsurface Precambrian plutonic rocks from the Brunovistulian Complex in the Bohemian Massif, Czechoslovakia. Precambr Res 62: 103-125

JoLivet L, FACCENnA C (2000) Mediterranean extension and the Africa-Eurasia collision. Tectonics 19: 1095-1106

Kalvoda J, Bábek O, Fatka O, Leichmann J, Melichar R, Nehyba S, ŠpaČek P (2008) Brunovistulian Terrane (Bohemian Massif, Central Europe) from Late Proterozoic to Late Paleozoic: a review. Int J Earth Sci 97: 497-518

Kempe U, Bombach K, Matukov D, Schlothauer Y, Hutschenreuter J, Wolf D, Sergeev S (2004) Pb/Pb and $\mathrm{U} / \mathrm{Pb}$ zircon dating of subvolcanic rhyolite as a time marker for Hercynian granite magmatism and $\mathrm{Sn}$ mineralisation in the Eibenstock granite, Erzgebirge, Germany: considering effects of zircon alteration. Miner Depos 39: 646-669

Kossmat F (1927) Gliederung des varistischen Gebirgsbaues. Abhandl Sächs Geol Landesamts 1: 1-39

Lancelot JR, Allegret A, Iglesias Ponce de Leon M (1985) Outline of Upper Precambrian and Lower Paleozoic evolution of the Iberian Peninsula according to $\mathrm{U}-\mathrm{Pb}$ dating of zircons. Earth Planet Sci Lett 74: 325-337

Le Maitre RW (2002) A Classification of Igneous Rocks and Glossary of Terms. Cambridge University Press, Cambridge, pp 1-236

Li ZX, Bogdanova SV, Collins AS, Davidson A, de Waele B, Ernst RE, Fitzsimons ICW, Fuck RA, Gladkochub DP, Jacobs J, Karlstrom Ke, Lu S, Natapov LM, Pease V, Pisarevsky SA, Thrane K, Vernikovsky V (2008) Assembly, configuration, and break-up history of Rodinia: a synthesis. Precambr Res 160: 179-210

Linnemann U, Gerdes A, Drost K, Buschmann B (2007) The continuum between Cadomian orogenesis and opening of the Rheic Ocean: constraints from LA-ICP-MS $\mathrm{U}-\mathrm{Pb}$ zircon dating and analysis of plate-tectonic setting (Saxo-Thuringian Zone, northeastern Bohemian Massif, Germany). In: LinNemann U, NAnce RD, Kraft P, Zulauf G (eds) The Evolution of the Rheic Ocean: From Avalonian-Cadomian Active Margin to Alleghanian-Variscan Collision. Geol Soc Am Spec Paper 423: pp 61-96

Loiselle MC, Wones DR (1979) Characteristics and origin of anorogenic granites. Geological Society of America, Abstracts with Programs 11: pp 468
LoRenz V, HANEKe J (2004) Relationship between diatremes, dykes, sills, laccoliths intrusive-extrusive domes, lava flows, and tephra deposits with unconsolidated water-saturated sediments in the late Variscan intermontane Saar-Nahe Basin, SW Germany. In: BreitKreuz C, PetFord N (eds) Physical Geology of High-Level Magmatic Systems. Geol Soc London Spec Pub 234: London, pp 75-124

Mazur S, Aleksandrowski P, Kryza R, Oberc-Dziedzic T (2006) The Variscan orogen in Poland. Geol Quart 50: $89-118$

Mazur S, Aleksandrowski P, Turniak K, Awdankiewicz M (2007) Geology, tectonic evolution and Late Paleozoic magmatism of Sudetes - an overview. In: KozLowski A, Wiszniewska J (eds) Granitoids in Poland. Arch Miner Monogr 1, Warszawa, pp 59-87

Montero P, Bea F, González-Lodeiro F, Talavera C, Whitehouse MJ (2007) Zircon ages of the metavolcanic rocks and metagranites of the Ollo de Sapo Domain in central Spain: implications for the Neoproterozoic to Early Paleozoic evolution of Iberia. Geol Mag 144: 963-976

Montero P, Bea F, Corretgé LG, Floor P, Whitehouse $\mathrm{MJ}$ (2008) U-Pb ion microprobe dating and $\mathrm{Sr}$ and $\mathrm{Nd}$ isotope geology of the Galiñeiro Igneous Complex. A model for the peraluminous/peralkaline duality of the Cambro-Ordovician magmatism of Iberia. Lithos, doi:10.1016/j.lithos.2008.10.009

Morris GA, Page L, Martinez V (2005) New dates (415 Ma) for the Etive Dyke Swarm and the end of the Caledonian Orogeny in the SW Grampian Highlands of Scotland. J Geol Soc, London 162: 741-744

Nasdala L, Götze J, Pidgeon RT, Kempe U, Seifert T (1998) Constraining a SHRIMP U-Pb age: micro-scale characterization of zircons from Saxonian Rotliegend rhyolites. Contrib Mineral Petrol 132: 300-306

NaWrocki J, Poprawa P (2006) Development of Trans-European Suture Zone in Poland: from Ediacaran to Early Paleozoic accretion. Geol Quart 50: 59-76

Oberc-Dziedzic T, Klimas K, Kryza R, Fanning CM (2003) SHRIMP U-Pb zircon geochronology of the Strzelin gneiss, SW Poland: evidence for a Neoproterozoic thermal event in the Fore-Sudetic Block, Central European Variscides. Int J Earth Sci 92: 701-711

Oberc-Dziedzic T, Kryza R, Kuimas K, Fanning MC, Madej S (2005) Gneiss protolith ages and tectonic boundaries in the NE part of the Bohemian Massif (Fore-Sudetic Block, SW Poland). Geol Quart 49: 363-378

Ogg JG, OgG G, Gradstein FM (2008) The Concise Geologic Time Scale. Cambridge University Press, Cambridge, UK, pp 1-177

OKRusch M, Richter P (1986) Orthogneisses of the Spessart Crystalline Complex, Northwest Bavaria: indicators of the geotectonic environment? Geol Rundsch 75: $555-568$ 
Oliver GJH, Corfu F, Krogh TE (1993) U-Pb ages from SW Poland: evidence for a Caledonian suture zone between Baltica and Gondwana. J Geol Soc, London 150: $355-369$

Oliver GJH (2001) Reconstruction of the Grampian episode in Scotland: its place in the Caledonian Orogeny. Tectonophysics 332: 23-49

Oliver GJH, Wilde SA, Wan Y (2008) Geochronology and geodynamics of Scottish granitoids from the late Neoproterozoic break-up of Rodinia to Palaeozoic collision. J Geol Soc, London 165: 661-674

PAN Y (1997) Zircon- and monazite-forming metamorphic reactions at Manitouwadge, Ontario. Canad Mineral 35:105-118

Parga-Pondal I, Matte P, Capdevila R (1964) Introduction à la géologie de 1' « Ollo de Sapo ». Formation porphyroïde antésilurienne du nord ouest de l'Espagne. Notas Comun Instit Geol Minero España 76: 19-154

PatočKa F, Valenta J (1996) Geochemistry of the late Devonian intermediate to acid metavolcanic rocks from the southern part of the Vrbno Group, the Jeseníky Mts. (Moravo-Silesian Belt, Bohemian Massif, Czech Republic): paleotectonic implications. Geolines 4: 42-54

Paulick H, Breitkreuz C (2005) The Late Paleozoic felsic lava-dominated large igneous province in northeast Germany: volcanic facies analysis based on drill cores. Int J Earth Sci 94: 834-850

Pearce JA, Harris NBW, Tindle AG (1984) Trace element discrimination diagrams for the tectonic interpretation of granitic rocks. J Petrol 25: 956-983

Pupin JP, Bonin B, Tessier M, Turco G (1978) Rôle de l'eau sur les caractères morphologiques et la cristallisation du zircon dans les granitoïdes. Bull Soc Géol France 7: 721-725

Reischmann T, Anthes G (1996) Geochronology of the Mid-German Crystalline Rise west of the River Rhine. Geol Rundsch 85: 761-774

Rickwood PC (1989) Boundary lines within petrologic diagrams which use oxides of major and minor elements. Lithos 22: 247-263

Romer RL, Förster HJ, BreitKreuz C (2001) Intracontinental extensional magmatism with a subduction fingerprint: the late Carboniferous Halle Volcanic Complex (Germany). Contrib Mineral Petrol 141: 201-221

Reischmann T, Anthes G, Jaeckel P, Altenberger U (2001) Age and origin of the Böllsteiner Odenwald. Mineral Petrol 72: 29-44

Salamon M, Flick H, Nesbor D, Königshof P, Schindler E, BRocke R (2008) Volcanism in the Lower Carboniferous and characteristic basinal settings in the Devonian. In: Königshof P, Linnemann U (eds) The Rheno-Hercynian, Mid-German Crystalline and Saxo-Thuringian Zones (Central European Variscides). Final meeting of IGCP 497 and IGCP 499 Excursion Guide, pp 79-88
Santos Zalduegui JF, Schärer U, Gil Ibarguchi JI (1995) Isotope constraints on the age and origin of magmatism and metamorphism in the Malpica-Tuy allochthon, Galicia, NW Spain. Chem Geol 121: 91-103

Simancas F, Expósito I, Azor, A, Martínez Poyatos D, GonzÁlez Lodeiro F (2004) From the Cadomian orogenesis to the Early Paleozoic Variscan rifting in southwest Iberia. J Iberian Geol 30: 53-71

SOPER NJ (1994) Was Scotland a Vendian RRR junction? J Geol Soc, London 151: 579-582

STAMPfli GM, BoREL GD (2004) The TRANSMED transects in space and time: Constraints on the paleotectonic evolution of the Mediterranean Domain. In: CAVAzZA W, Roure F, SPAKman W, Stampfli GM, Ziegler P (eds) The TRANSMED Atlas: the Mediterranean Region from Crust to Mantle. Springer-Verlag, Berlin, pp 53-80 and CD ROM

Steinhoefel G, Hegner E, Oliver GJH (2008) Chemical and $\mathrm{Nd}$ isotope constraints on granitoid sources involved in the Caledonian Orogeny in Scotland. J Geol Soc, London 165: 817-827

Thelin P (1987) Nature originelle des gneiss œillés de Randa (Nappe de Siviez-Mischabel, Valais). Mémoires Soc vaudoise Sci Natur 18: 1-75

Tomaschek F, Kennedy AK, Villa IM, Lagos M, Ballhaus C (2003) Zircons from Syros, Cyclades, Greece - Recrystallization and mobilization of zircon during highpressure metamorphism. J Petrol 44: 1997-2002

Valverde-Vaquero P, Marcos A, Farias P, Gallastegui G (2005) U-Pb dating of Ordovician felsic volcanism in the Schistose Domain of the Galicia-Trás-os-Montes Zone near Cabo Ortegal (NW Spain). Geol Acta 3: 27-37

van Breemen O, Aftalion M, Johnson MRW (1979) Age of the Loch Borrolan Complex, Assynt, and late movements along the Moine Thrust Zone. J Geol Soc, London 136: 489-495

WedePoHL KH (1991) Chemical composition and fractionation of the continental crust. Geol Rundsch 80: 207-223

Whalen JB, Currie KL, Chappell BW (1987) A-type granites: geochemical characteristics, discrimination and petrogenesis. Contrib Mineral Petrol 95: 407-419

Williams IS, Claesson S (1987) Isotopic evidence for the Precambrian provenance and Caledonian metamorphism of high grade paragneisses from the Seve Nappes, Scandinavian Caledonides. II. Ion microprobe zircon U-Th-Pb. Contrib Mineral Petrol 97: 205-217

ZeH A, BRÄTz H (2002) Timing of Late Carboniferous-Permian granite and granite porphyry intrusions in the Ruhla Crystalline Complex (Central Germany), new constraints from SHRIMP and ${ }^{207} \mathrm{~Pb} /{ }^{206} \mathrm{~Pb}$ single zircon dating. Chem Erde 62: 303-316

Zeh A, Cosca AM, Brätz H, OKrusch M, Tichomirowa M (2000) Simultaneous horst-basin formation and magmatism during Late Variscan transtension: evidence from 
${ }^{40} \mathrm{Ar} /{ }^{39} \mathrm{Ar}$ and ${ }^{207} \mathrm{~Pb} /{ }^{206} \mathrm{~Pb}$ geochronology in the Ruhla Crystalline Complex. Int J Earth Sci 89: 52-71

Zeh A, Gerdes A, Will TM, Millar IL (2005) Provenance and magmatic-metamorphic evolution of a
Variscan island-arc complex: constraints from $\mathrm{U}-\mathrm{Pb}$ dating, petrology, and geospeedometry of the Kyffhäuser Crystalline Complex, Central Germany. J Petrol 46: $1393-1420$ 